\title{
Analysis of Illocutionary Acts on English Teachers' on Teaching Process in Classroom at SMPN 01 Patamuan Padang Pariaman
}

\author{
Leni Herfina ${ }^{1, *}$ \\ ${ }^{1}$ English Education Program, University Negeri Padang, Indonesia \\ *Corresponding author. Email: herfinal341@gmail.com
}

\begin{abstract}
This research uses a qualitative approach. This type of research is descriptive research. The data collection technique was carried out by observation, while the data analysis technique used was qualitative descriptive technique and pragmatic analysis. The purpose of this study was to analysis of illocutionary act on English teachers in teaching and learning at SMPN 01 Patamuan Padang Pariaman. This study used a qualitative research method based on Yule's 1996 theory. The results showed that the meaning contained in illocutionary acts consisted of four components, namely representative, directive, expressive, Commissive, and declarative components. These found for English teacher one and two 255 utterances, indicate that representative of 55 utterances then directive 75 utterances then 60 expressive utterances and 65 Commissive utterances and no declarative utterances. And the most dominant component of illocution is directive, namely asking
\end{abstract}

Keywords: speech act, illocutionary act, Teachers' English, and teaching Learning Process

\section{INTRODUCTION}

\subsection{Pragmatics}

Pragmatics based on expert is another broad approach to discourse. It deals with three concepts, it is meaning, context and communication that are they extremely fast and unwieldy. Pragmatics is the study of how the relation of signs to interpreters, then pragmatics is the study of how interpreters engage in the taking account of designates the construction of interpreting of sign vehicles, based on Debora Schifrin's book [1].

While Grice definition on Pragmatics is speaker meaning, not only allows a distinction between two kinds a meaning namely and hence, a division between semantic and pragmatics meaning, also suggest a particular view of human communication that focuses to intentions, based on Schifrin's book [1]. Another definition, 'Pragmatics has a particular study or field of study, namely diexis, presupposition, speech acts, and Conversational Implicature','[2]

Pragmatic is one of the branches of linguistics that studies the use of grammar and has branches including phonology, morphology, syntax, and semantics [3] while according to Yule [4] opinion, pragmatics is the study of the speaker's meaning and then the study of meaning. From the original context, how pragmatics is about spoken communication and the last is pragmatics is about what the speaker expresses. Based on Yule [4]. it can be concluded pragmatics is study about contextual meaning, speaker meaning and expression of speaker to listener and pragmatic have sub category like speech act. Based on definition above, pragmatics is approach to discourse and study how meaning, context and communication relation with interpreter.

\subsection{Speech act}

In communicating of course, there are speech acts. The speech act itself is part of the study of pragmatics. Speech act begins with the work of John Austin, whose ideas are expanded and incorporated into linguistics theory by John Searle. Searle [5] 'Explained that the speech act has 5 components, namely representative, directive, expressive, Commissive and declarative. Speech act based Searle proposes that the speech act is the basic unit of communication, speech act builds upon Austin work to propose a systematic framework by which to incorporate speech act into linguistics theory. Yule [4] states that "speech acts is action performed via utterance, and in English are commonly given more specific labels, such as apology, complaint, compliment, invitation, promise, or request' 'Speech act based on Yule [4] states that speech acts are a study of how the speakers and hearers use language. Second, utterances that perform an action are generally. Based on those opinions above, it can be concluded that speech act is a speech made by the speaker in a speech. 
Based on Yule [4], type of speech act are locutionary, illocutionary and perlocutionary. The purpose of Illocution According to Yule [4] is expressions of utterances that have a certain meaning and are carried out through communicative utterances which have various types of functions. According to Atchison [6] a speech act is a sequence of utterances that are performed. So illocution is composed of illocutionary forces and propositional charges.

\subsection{Illocutionary}

Illocutionary acts is an action taken by a speaker in a speech related to the intention of the speaker, for example stating, questioning and other adapted by Yule [4]. Austin [7] defines illocution is something that is carried in a word and sentence. Illocutionary acts can be seen from a communicative speech with various types and functions. Searle categorizes illocutionary acts into five types, namely:

1. Assertive

Speech acts that describe circumstances or events, such as reports, demands and statements. Example: "' tomorrow there will be a test at 08.00 sharp "

2. Directive

The form of speech intended by the speaker to make an impact so that the speech partner takes actions such as suggestions, requests, and orders. Example: "Please sit down!"

3. Expressive

Speech acts used by speakers to express feelings and attitudes towards something. Example: "Students are very handsome."

4. Commissive

The form of speech that functions to express something in the future, such as a promise or threat. Example: " Grandma is going to Surabaya tomorrow with my sister"

5. Declarative

Speech acts that can change circumstances. Example: "she says tomorrow you have to go to school". These words change a person's status from an immature state to a pass state.

Meanwhile, the Illocutionary act is the act of carrying out an action in a speech [7]. Then the illocutionary act according to Searle [5] is divided into 5 components, namely representative, directive, Commissive, declarative, and expressive. The following is an explanation of each component according to Yule [4], which is as follows:

a. "Representatives or Assertive states that representatives are types of illocutionary act that commit the speaker believe about something the truth or not. In performing this type of illocutionary act, it can be noted by some performative verbs, such as: state, tell, assert, correct, predict, report, remind, described, inform, assure, agree, guess, claim, believe, conclude, etc
Examples:

The earth is flat (Stating a fact)

Chomsky didn't write about peanuts (Stating an opinion)

It was a warm sunny day (Describing).

b. 'Declaratives is change the world via their utterances, the speaker has to have special institutional role, in a specific context. declarative include: pronounce, declare, baptize and sentence, announce, declare, define, appoint, call, bless, nominate and etc

Examples:

Give me a cup of coffee; Make it black for (Commanding or ordering)

Could you lend me a pen please for (Requesting?)

Don't touch that (Forbidding)

c. 'Commissive are kind of illocutionary act that is commit the speaker to some future course of action and In performing this type of illocutionary act, include: ask, order, command, and etc

Examples:

I'll be back (Promising)

I'm going to get it right next time (Promising)

We will not do that (Refusing)

d. "Declarative is included as a component of illocutionary action which changes the world through his speech, so the speaker must have a special institutional role, in a certain context. Declarative includes: pronounce, state, baptize and sentence, announce, declare, define, designate, call, bless, nominate and others.

Examples:

I now pronounce your husband and wife (Marrying)

You are out! (Firing)

We find this defendant guilty. (Sentencing)

e. 'Expressive are kind of illocutionary act that state what the speaker feels. To convey a psychological state and it can be in the form of statements of joy, pain, joy, joy or sorrow, surprise, apologies, gratitude, In using expressiveness, the speaker makes words according to feelings, In expressing it, it can be noted with a few words performative work: greeting, surprise, like, fear, apology, gratitude, regret, and praise

Examples:

I'm really sorry! (Apologizing)

Congratulations! (Congratulating)

Mmmm.. Sssh. (Stating pleasure)

The study of speech acts is an important study in Pragmatics. This refers to Rustono's [8] explanation that "speech acts are a central entity in pragmatics so that speech acts become the basis for analysis of other pragmatic topics, such as presuppositions, conversational implicatures, principles of cooperation, and the principle of politeness." 


\subsection{Context}

Context is information that identification in relation with to something else is the primary focus of attention people; it means that it is impossible to talk about context; context cannot exist unless thinking of something else. Example; an image, a smell, a sound, a word, an utterance, and a sequence of utterances. To understand the meaning conveyed by the speaker, the interlocutor must pay attention to the context of the speech. If the context of the speech is different, the meaning of the speaker will be different. Rahardi [9] states that "the context of speech has been interpreted in various ways by linguists. Context can include aspects of speech that are both physically and non-physically relevant. Context can also be interpreted as all the background knowledge which is assumed to be shared by speakers and speech partners and which supports the interpretation of the speech partner of what the speaker means in the speech process".

The researcher focuses on the illocutionary act speech act because it is closely related to the learning process in which there is an interaction between the teacher and students, which has the intention of the speech that is in accordance with the context that occurs.

\section{RESEARCH METHODS}

There are three types of designs research are advanced: qualitative, quantitative, and mixed methods [10]. Approach this research is qualitative. Qualitative is a study how to exploring based on means from a speaking or utterances from a data like an individual or group. The data collected by utterances of English teachers, there are two teachers in collected [10]. The qualitative approach emphasizes the acquisition of original data or natural conditions [11]

This type of research is descriptive research. Opinion from Nazir [12] states that "Descriptive research is a method used in examining an object or set of conditions, systems of thought, or class at the time the utterance occurred'. In addition, in analyzing data, researchers also use pragmatic analysis, namely language analysis based on a pragmatic point of view [8].

This research at SMPN 01 Patamuan, the research is analysis English teacher in here with observation, Thus, the researcher apply the data of analyzing of speech act especially illocutionary act by George Yule [4] Based on pre-observation to school Population is all of English teacher of SMPN 1 Patamuan. A total English teacher in this school is four people. In instrument that use by researcher in this case is the human being, while the supporting instrument is interview and recording. During the observation, researcher used video recorder and note taking to collect the data. Video recorder will use as an instrument in order to cover all the learning and teaching process.
This research focus on analysis of illocutionary act by English teacher SMPN 01 Patamuan.To describe how illocutionary speaking and result of utterances. Researcher focus found utterances of speaking English teacher in teaching learning. This study aims to describe how illocutionary English teachers perform. Specifically, the objectives of this study are: to classify the illocutionary act used by English teachers at SMPN 1 Patamuan, to describe the contextual meanings of these illocutionary act, and to describe the meaning contained in the illocutionary speech.

\section{RESULT AND DISCUSSION}

The research is analysis of English teacher in SMPN 01 Patamuan in teaching learning based on Yule's theory. The research found four components of illocutionary acts, namely representative, expressive, directive and Commissive. So the result is follows;

\subsection{Component of illocutionary act from English teacher in teaching learning in classroom.}

Based on research conducted by researchers, namely the analysis of illocutionary act by the English teachers' at SMPN 01 Patamuan can be seen as follows. Researchers do analysis Wednesday 24 march 2020, date 10.00- 11.00, class; VII1, VII2 and the topic: Narrative text and procedural text

\subsubsection{Component of illocutionary act from English teacher (for teacher 01)}

In opening activity, so, researcher found that there are expressive, in expressive include welcoming, representative, in representative include confirming and directive, in directive include asking. In expressive found that 3 utterances. Found that 1 utterances in representative in opening. In exploration found that, there are Representative including Explaining and Concluding found 12 utterances, and directives include asking, confirming, requesting and forbidding found 59 utterances. Then, Elaboration there is Directive. In directive there is requesting found 5 utterances, then, Representative including Confirming found 1 utterances, and Commissive there is requesting found 5 utterances. In closing found there are Commissive, in Commissive there is promising found 1 utterance, and representatives, in representative there is leaving found 1 utterance

\subsubsection{Component of illocutionary act from English teacher (for teacher 02)}

In opening activity found 2 utterances for representative include confirming and 3 utterances directives into asking. In exploration found representative and directives. In representative found 21 utterances for explaining, confirming 10 utterances and 1 utterance for concluding. In exploration found directives and representatives. In directive found Asking 23 utterances, Requesting 2 
utterances, and Commanding 2 utterances, suggesting 5 utterances, and forbidding 1 utterance. In elaboration found directive and representative. In representative found 1 utterance, for asking requesting 4 utterances, and commanding 3 utterances. In Representative found 1 utterance for Explaining and 1 utterance for Confirming. And finally closing found expressive and Commissive. In expressive found 2 utterances for promising, then Commissive found 2 utterances for leaving.

\subsection{Dominant component of illocutionary act from English teacher in teaching learning in classroom}

Based on data above dominant component of illocutionary act in English teachers' in SMPN 01 Patamuan, representative get 30 utterances, expressive get 30 utterances, directive get 40 utterances and Commissive get 20 utterances and there is no declarative. So dominant component is directive namely asking

\section{DISCUSSION}

Based on analysis data above, found that 200 utterances namely representative, directive, expressive and last one Commissive. From the representative 20 utterances, Commissive 20 utterances, expressive 20 utterances and directives 30 utterances. So, dominant component of the illocutionary is directive namely sub category in directive is asking from teacher English SMPN 01 Patamuan. It can be said that analysis illocutionary act by English teacher SMPN 01 Patamuan, researcher found four component of illocutionary act namely representative, expressive, Commissive and directive. While declarative didn't found in utterances English teachers'.

\section{CONCLUSION}

This study is related to pragmatic analysis, namely analyzing the illocutionary act of English teachers in teaching and learning at SMPN 1 Patamuan. This study identifies the illocutionary act by English teachers at SMPN 1 Patamuan. The conclusion is as follows

In analyzing the data, the researcher found that four of the five components of the illocutionary act by the English teacher at SMPN 01 Patamuan during the teaching and learning process, there are speech acts by the teacher from 255 utterances. Namely directive, representative, expressive and Commissive, while declarative is not found in this analysis because usually this declarative is usually found in a special institution.

The most common or the most dominant used by English teachers is directives during the teaching and learning process, because in the teacher's directive many ask students to take action. In addition, it is the declarative thing that is rarely used by teachers in the teaching and learning process.

\section{ACKNOWLEDGMENT}

I would like to express my sincere appreciation to my husband, my mom and my family.

\section{REFERENCES}

[1] D. Schiffrin, Approaches to discourse: Language as social interaction. London, England: Blackwell, 1994.

[2] B. K. Purwo, Pragmatik dan pengajaran bahasa: Menyibak Kurikulum 1984. Yogyakarta: Kanisius, 1990.

[3] G. N. Leech, Principles of pragmatics. London, England: Routledge, 2016.

[4] G. Yule, Pragmatics. London, England: Oxford University Press, 1996.

[5] J. R. Searle, Speech acts: An essay in the philosophy of language. Cambridge, England: Cambridge University Press, 2013.

[6] J. Aitchison, Teach yourself linguistics. Teach Yourself, 2004.

[7] J. L. Austin, How to do things with words: Second edition, 2nd ed. London, England: Harvard University Press, 1975.

[8] Rustono, Pokok-Pokok Pragmatik. Semarang: IKIP Semarang Press, 1999.

[9] R. K. Rahardi, Pragmatik: kesantunan imperatif bahasa Indonesia. Jakarta: Erlangga, 2005.

[10] J. W. Creswell, Research design: Qualitative, quantitative, and mixed methods approaches, 4 th ed. Thousand Oaks, CA: SAGE Publications, 2014.

[11] S. Arikunto, Metode penelitian kualitatif. Jakarta: Bumi Aksara, 2006.

[12] M. Nazir, Metode penelitian. Jakarta: Ghalia Indonesia, 1988. 